Agata Zakrzewska', Magdalena Szczepanowska', Janina Książek², Iwona Biadacz', Robert Dziedzic', Małgorzata Jelitto-Górska ${ }^{3}$, Witold Rzyman'

'Department and Teaching Hospital of Chest Surgery, Medical University of Gdańsk Head: Prof. W. Rzyman, MD, PhD

${ }^{2}$ Unit of Surgical Nursing, Medical University of Gdańsk

Head: J. Książek, MD

${ }^{3}$ Radiology Unit, Medical University of Gdańsk

Head: E. Szurowska, MD, PhD

\title{
The influence of selected factors on the attendance of the high-risk population in the early lung cancer detection program
}

\author{
Analiza czynników wpływających na zgłaszanie się osób zagrożonych \\ zachorowaniem na raka płuca do programu wczesnego wykrywania
}

The authors declare no financial disclosure

\begin{abstract}
Introduction. Lung cancer is the most common cause of cancer-related death worldwide, killing almost 22,000 people in Poland every year. Low-dose computed tomography (LDCT) is the most promising tool of secondary prophylaxis leading to early detection and thus successful treatment of this malignancy. Knowledge about socio-demographic factors that affect participation in lung cancer early detection programs is essential for the future design and implementation of such programs.

Material and methods: Among the 8649 participants of the Pomeranian Lung Cancer Screening Program (PLCSP), 1619 individuals responded to a questionnaire that had been designed to assess socio-demographic data of participants at high risk of developing lung cancer. The survey was conducted on-site after reception of results by the program participants.

Results: Among the survey participants, 777 (48\%) were current cigarette smokers. The majority of them represented low or medium level of wealth status. The respondents positively evaluated the promotional campaign during the PLCSP, although $43 \%$ of them indicated family and friends as a source of information about the program. As the most important action that stimulated the participation, $46 \%$ of the respondents indicated the awareness campaign involving a celebrity, and $45 \%$ of them indicated the presence of cancer in the family. The influence of healthcare employees on the participation in the screening program was minimal. More than half of the respondents $(53 \%)$ declared a willingness to co-finance a similar prophylactic program in the future in an amount not exceeding 100 PLN.

Conclusions: An effective promotional campaign in the media, the influence of family and a campaign involving a celebrity promoted attendance at the screening program. The influence of healthcare employees on the participation in the program was minimal. The majority of the screened population declared a willingness to actively participate in the costs of LDCT examination.
\end{abstract}

Key words: lung cancer, early detection, screening, low-dose computed tomography

Pneumonol. Alergol. Pol. 2014; 81: 25-31

\section{Streszczenie}

Wstęp: Rak płuca jest jednym z najczęściej występujących nowotworów złośliwych w Polsce i na świecie. W Polsce powoduje zgon niemal 22000 osób rocznie. Obecnie największe nadzieje na wczesne wykrywanie tego nowotworu, a tym samym jego skuteczniejsze leczenie, wiąże się z niskodawkową tomografią komputerową (LDCT). Podczas projektowania i realizacji programów wczesnego wykrywania nowotworów szczególnie istotna jest znajomość uwarunkowań socjodemograficznych wpływających na zgłaszalność uczestników.

Address for correspondence: Agata Zakrzewska, MSc, Department and Teaching Hospital of Chest Surgery, Medical University of Gdańsk, ul. Mariana Smoluchowskiego 17, 80-214 Gdańsk, tel.: + 485834931 30, fax: +48 5834924 44, e-mail: agatazakrzewskaxx@gumed.edu.pl 10.5603/PiAP.2014.0005 


\begin{abstract}
Materiał i metody: Badaniem objęto 1619 kolejnych osób z 8649, które zostały poddane LDCT w ramach Pomorskiego Pilotażowego Programu Badań Przesiewowych Raka Płuca (PPPBPRP). Badanie przeprowadzono z wykorzystaniem ankiety oceniającej dane społeczno-demograficzne uczestników należących do grupy wysokiego ryzyka zachorowania na raka płuca.

Wyniki: Wśród uczestników PPPBPRP znalazło się 777 (48\%) aktualnych palaczy tytoniu. Większość z nich reprezentowała niski lub średni stopień zamożności. Badani pozytywnie ocenili sposób przeprowadzenia kampanii promocyjnej programu, jednak $43 \%$ z nich wskazało rodzinę i znajomych jako równie ważne źródło uzyskiwania wiedzy o projekcie. Za główny bodziec skłaniający do brania udziału w podobnym programie $46 \%$ uczestników wskazało kampanię informacyjną z udziałem osoby popularnej, a $45 \%$ z nich wystąpienie nowotworu u członka rodziny. Minimalny okazał się wpływ pracowników ochrony zdrowia na zglaszanie się uczestników na badanie wczesnego wykrywania raka płuca. Ponad połowa badanych $(53 \%)$ zadeklarowała gotowość współfinansowania podobnego programu profilaktycznego w kwocie nie przekraczającej 100 PLN.

Wnioski: Skuteczna kampania reklamująca prowadzenie badań wczesnego wykrywania raka płuca w mediach, wpływ rodziny oraz prowadzenie kampanii reklamowej z udziałem popularnej osoby mają największy wpływ na zgłaszalność. Wpływ pracowników ochrony zdrowia na zgłaszalność jest znikomy. Deklarowana przez uczestników gotowość do wspóffinansowania badań jest istotna ze względu na możliwość zredukowania wysokich kosztów prowadzenia programów profilaktycznych opartych o wykorzystanie techniki LDCT.
\end{abstract}

Słowa kluczowe: rak płuca, wczesne wykrywanie, skrining, niskodawkowa tomografia komputerowa

Pneumonol. Alergol. Pol. 2014; 81: 25-31

\section{Introduction}

Apart from primary prophylaxis of lung cancer (anti-smoking interventions), early detection is the best strategy to significantly reduce mortality caused by the most frequent neoplasm in Poland. Among numerous available tools to conduct such programs, low-dose computed tomography (LDCT) seems to be the most promising. In 2006, Henschke et al. [1] analysed the results of surgical treatment of lung cancer patients diagnosed by LDCT within the International Early Lung Cancer Action Program (I-ELCAP). Ten-year survival was noted in 412 (88\%) out of all patients with non-small cell lung cancer (NSCLC) diagnosed within I-ELCAP, whereas in 302 patients who were treated surgically within 30 days from diagnosis, ten-year survival was $92 \%$. The use of LDCT for lung cancer screening programs has become more popular after publication of the results of the National Lung Cancer Screening Trial (NLST), which showed a 20\% reduction in mortality rate among individuals monitored with the use of LDCT, compared to the group controlled by X-ray examination of the chest [2]. Many papers showing the results of clinical trials concerning early detection of lung cancer with the use of LDCT have been published to date [1-10]. Although we know many aspects of the use of LDCT as a tool to detect early lung cancer, there still remain many unanswered questions. In the present paper we demonstrate some results concerning the attendance at the Pomeranian Lung Cancer Screening Program (PLCSP) that was held in Gdańsk in the years 2008-2011.

\section{Material and methods}

The study was conducted in 2010 in the Teaching Hospital of Chest Surgery at the Academic Clinical Centre in Gdańsk on a group of 1619 individuals (834 males and 785 females) who consented to complete a questionnaire. We obtained the consent of the Independent Bioethics Committee for Scientific Research at the Medical University of Gdańsk (NKEBN/79/2011). The presented project constituted a part of the PLCSP that was conducted in the period from November 2008 to April 2011. As part of the program, a total of 8649 healthy inhabitants of the Pomeranian region from a group at high-risk of lung cancer incidence, in the age group 50-75 years and with history of cigarette smoking at least 20 pack-years, underwent free-of-charge chest examination with the use of LDCT. In the case of family history, the number of pack-years was reduced to 10 . People interested in participating in the PLCSP had several possibilities to obtain information about the program - from the website, press, $\mathrm{TV}$, radio, leaflets, posters and healthcare employees. Applications were made through the website, hotline and through personal contact. Computed tomography examinations were performed in 19 radiological facilities in the Pomeranian region. The patients who had changes detected in the chest were directed, depending on the size of tumour, to LDCT follow-up examinations or further invasive diagnosis at the Teaching Hospital of Chest Surgery, according to the following algorithm: tumours of diameter greater than 10 $\mathrm{mm}$ or suspected malignancy - diagnosis at the Teaching Hospital; tumours of 5-10 mm diameter 
- a series of three LDCT follow-up examinations after 3, 6 and 12 months; and tumours of diameter less than $5 \mathrm{~mm}$ - one follow-up LDCT examination after 12 months. During the PLCSP, lung cancer was detected in 85 patients.

The study was conducted with the help of the original questionnaire that evaluated social and demographic data, i.e. sex, age, education, number of persons in the household, number of under-age children to maintain, number of family members who smoke cigarettes, monthly per capita net income in the household, and access to the Internet. The questionnaire included questions concerning the way of obtaining the information about the program, reason for attendance at the examination, availability of the program, effectiveness of promotion thereof, reaction to the obtained results, conducted lifestyle, participation in other preventive programs and payment for the examination. The questionnaire was completed in the presence of the person who had performed the examination, on receipt of the results and after they were read, so that in case of any questions or doubts the respondent could receive help. The respondent was marked on a 5-degree scale, representing the extent to which he or she agreed with the statements presented in the questionnaire (1 meant "I definitely disagree", 2 - "to some extent I disagree", 3 - "I have no opinion", 4 "I possibly agree" and 5 - "I definitely agree").

The aim of the study was to obtain knowledge about the assessment of the program by its participants, in order to be able to effectively carry out similar programs in the future. Information concerning the following was particularly valuable: the way of obtaining information about the possibility of participating in the program, factors that convinced the participants to attend the program, evaluation of accessibility of examinations, and the participant's opinion about possible introduction of payment for the examination in future. Moreover, we examined the participants' reactions to the information about the presence of tumours in the lung parenchyma, and their opinion on possible consequences of the occurrence of such pathology. We also asked for their willingness to participate in similar preventive programs, also in ones that required payment.

\section{Results}

Among the 1619 participants of the study, the mean of age was 60 years, and the participation of women and men was almost equal, amounting to $49 \%$ and $51 \%$, respectively. The proportion of individual age groups among the participants of the project is presented in Fig. 1. A total of 311 respondents (19.2\%) declared that they lived off their pensions. Among the respondents, 1025 persons (63.3\%) lived alone or in households consisting of 2 persons. The vast majority of respondents (1452, 89.7\%) did not have children to support. During the project, 777 respondents (48\%) were current tobacco smokers. 329 persons $(20.3 \%)$ admitted that their spouse smoked cigarettes, 149 persons (9.2\%) - that their adult

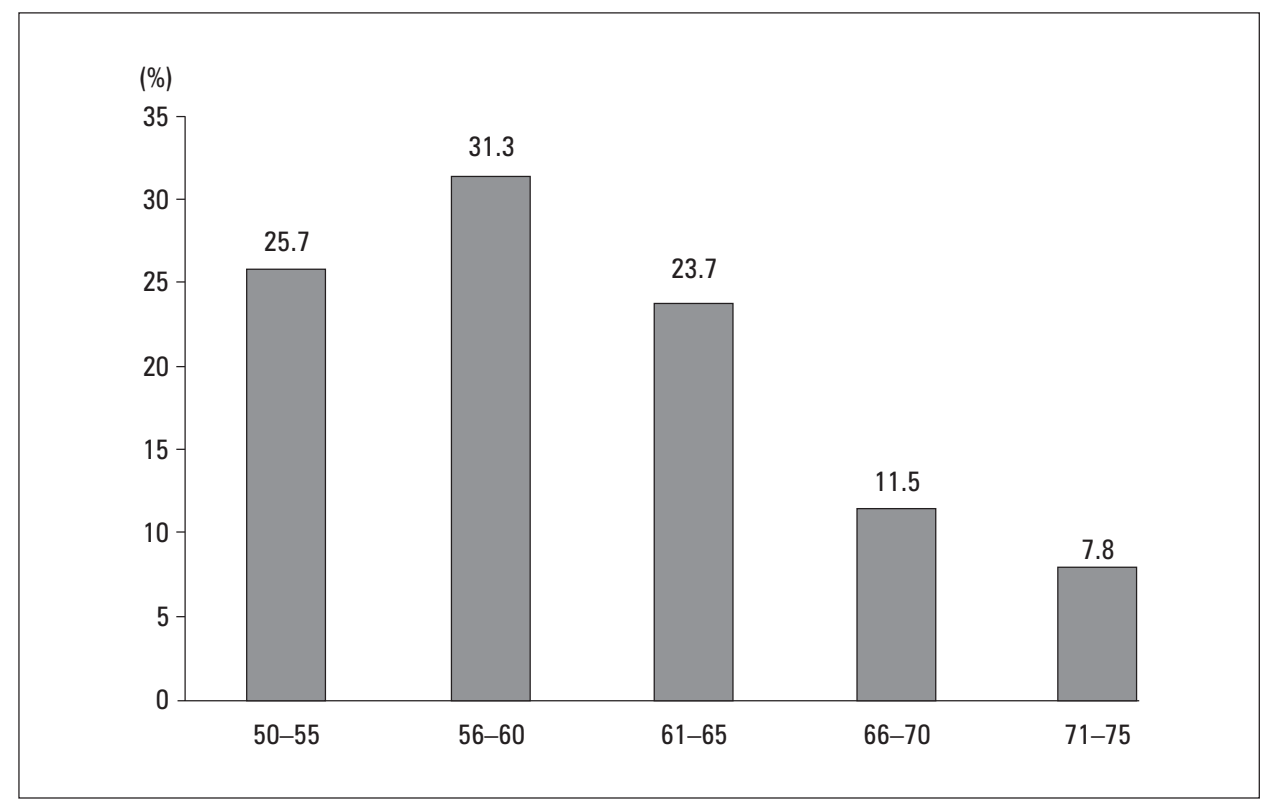

Figure 1. Age of the study population (years)

Rycina 1. Wiek uczestników programu (lata) 


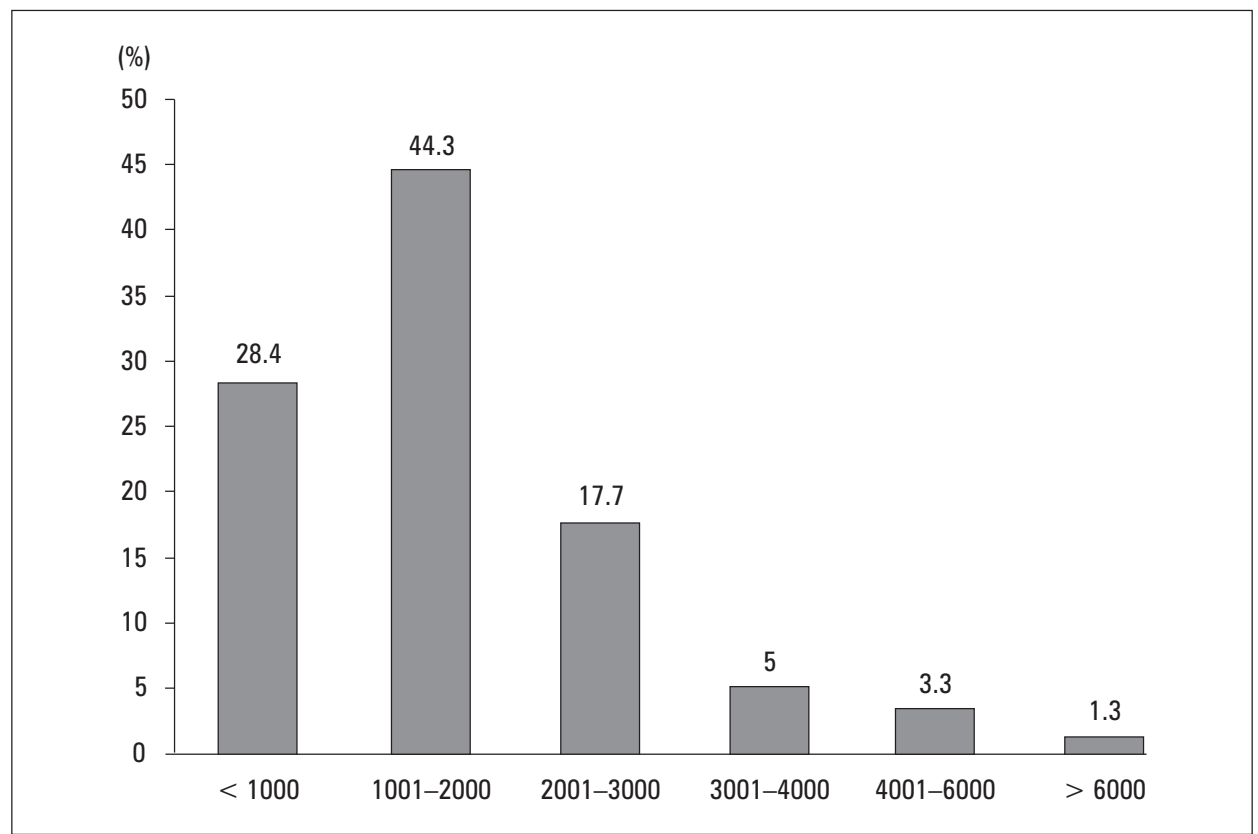

Figure 2. Approximate monthly per capita net income in the household (PLN)

Rycina 2. Przybliżony miesięczny dochód netto przypadający na członka rodziny (PLN)

children smoked cigarettes, and 34 persons $(2.1 \%)$ - that their parents or in-laws smoked cigarettes. The approximate monthly per capita net income in the household is presented in Fig. 2. Income not exceeding the amount of 1000 PLN was declared by 460 respondents (28.4\%), whereas income in the range of 1001 to 2000 PLN was declared by 717 persons (44.3\%). A total of 1023 participants of the program (63.2\%) had access to the Internet, and 711 persons (43.9\%) used it everyday or at least several times per week. Only 309 respondents used the website of the PLCSP. The reported sources of information about the program are presented in Fig. 3.

In the case of 928 persons (57.3\%) who entered the study, the decision to attend the screening examination was made independently, whereas 638 respondents (39.4\%) indicated the complete or partial influence of a third party on making such a decision. The respondents were asked to indicate the most important incentive to attend the LDCT examination. Among the answers given in the questionnaire were the following: the occurrence of neoplasm in a family member (730 persons, $45.1 \%$ ), promotional campaign in the media involving a celebrity (751 persons, $46.4 \%$ ), and to a lesser degree - the occurrence of a neoplasm in a famous person (402 persons, 24.8\%). The survey participants were also asked whether, in the case of the occurrence of worrying symptoms or a follow-up LDCT recommended by a physician,

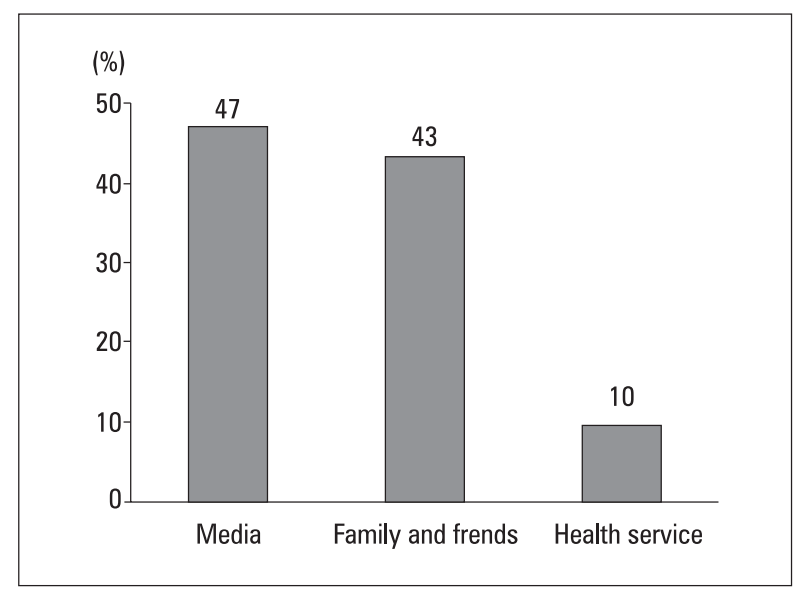

Figure 3. The sources of information about the program

Rycina 3. Źródła uzyskiwania przez uczestników wiedzy o programie

they would decide to have such an examination. 567 persons (35\%) declared a definite readiness to have the examination if worrying symptoms occurred, whereas 591 persons (36.5\%) would not have the examination in such a case. If CT was recommended by a doctor, 879 respondents (54.3\%) would have it, while 686 participants $(42.4 \%)$ would not participate in the examination.

The majority of persons (1190, 73.5\%) said that the CT examination performed as part of the PLCSP was made in a facility that was situated close to their place of residence. For the majority of persons (1047, 64.7\%), the distance from their 


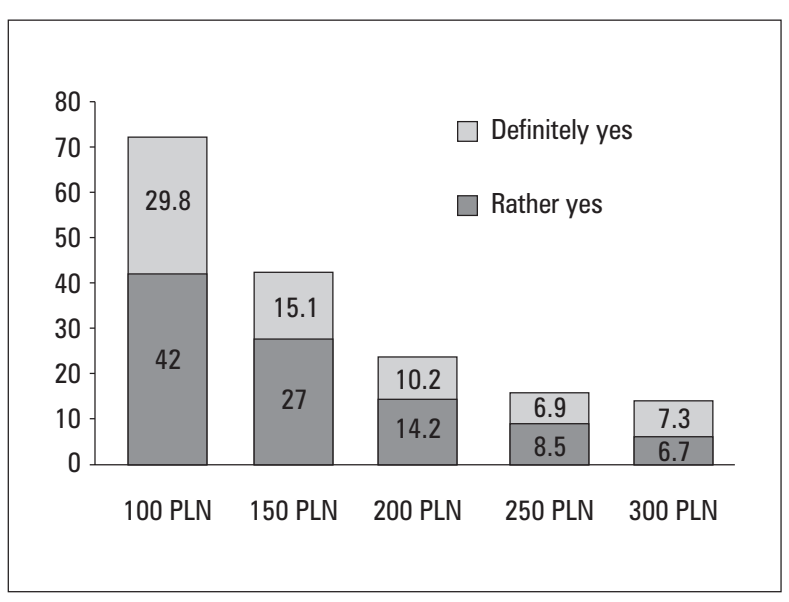

Figure 4. The potential financial participation of high-risk individuals in an annual prophylactic chest low-dose computed tomography

Rycina 4. Kwota, jaką respondenci byliby w stanie zapłacić za coroczne odpłatne profilaktyczne badanie klatki piersiowej metodą niskodawkowej tomografii komputerowej

place of residence to the facility in which the examination was performed was unimportant and did not influence their participation in the program. If the examination was made free-of-charge but in a remote facility, readiness to participate in the program was be declared by 1153 persons (71.2\%). In the case when the program did not offer CT examination free-of-charge, 502 persons (31\%) would decide to participate in a payable examination in a facility remote from their place of residence, whereas 724 persons (44.7\%) would not attend the program. On the other hand, nearly $50 \%$ of participants (809 persons) would decide to make a payable examination in a facility located close to their place of residence. The respondents who were willing to perform a payable examination were asked which of the following proposed amounts they would be prepared to pay for the examination: 100 PLN, 150 PLN, 200 PLN, 250 PLN or 300 PLN. More than half of the respondents $(425,52.5 \%)$ chose the lowest proposed cost of the examination at the amount of 100 PLN.

Changes in lung parenchyma were not found in 664 cases (41\%); therefore, the participants were informed that they did not need to perform a follow-up examination within the PLCSP program. 555 persons $(34.3 \%)$ were recommended to perform a series of three follow-up examinations 3,6 and 12 months from the date of the first test. In 334 cases (20.6\%), one follow-up examination after 12 months from the date of the first test was recommended. A total of 66 persons (4.1\%) were sent for further invasive diagnosis in the Teaching Hospital. One of the points in the questionnaire concerned associations and consequences connected with the information about the presence of the tumour/nodule in the lung parenchyma. In opinion of 763 respondents (47.1\%), such information meant neoplasm, whereas for 325 persons $(20.1 \%)$ it meant lung cancer. The participants were asked whether in the future they would perform prophylactic examinations of the lungs in order to detect early forms of neoplasm. Almost all respondents (1507 answers, 93.1\%) said that they would choose to participate in another, similar program. The amount that the participants would be able to pay for an annual paid prophylactic examination of the lungs with the use of LDCT is presented in Fig. 4.

The respondents were also asked to assess the promotional campaign of the PLCSP. 716 persons $(44.2 \%)$ thought that the information about the possibility of an examination obtained from a general practitioner was insufficient. Similarly, information from a community nurse was thought to be deficient (903 answers, 55.8\%). 984 persons (60.8\%) considered the promotional campaign to be effective. 1509 respondents (93.2\%) expressed the opinion that a general practitioner, and to a lesser extent, a community nurse (895 answers, 55.3\%), should be the person who informs patients about programs concerning early detection of lung cancer. The clear majority of respondents (1473, 91\%) thought that such information should be spread through promotional campaigns in the media.

\section{Discussion}

Lung cancer is the most frequent neoplasm in the world; it causes almost as many deaths as the next four most frequently occurring neoplasms [11]. According to the National Cancer Registry, 21,000 patients are diagnosed with lung cancer in Poland every year, and more than 22,000 patients die due to this disease [12]. Numerous epidemiological studies have shown that lung cancer is a multifactorial disease, however, and the biggest direct influence on the risk of the disease is connected with long-lasting exposure to tobacco smoke, which is responsible for at least $80 \%$ of diagnosed lung cancer cases [1, 13]. Therefore, lung cancer patients are perceived as the persons who are responsible for the disease. Additionally, due to a lack of knowledge about the neoplasm in society, patients often ignore the first symptoms of the disease. Consequently, lung cancer is often diagnosed too late to treat the patient effectively.

For many years medical institutions throughout the world have been trying to minimize 
the social costs of late detection of lung cancer, through numerous prophylactic programs with the use of different techniques [1-10, 14-18]. When the results of the NLST were published, interest in the use of LDCT in early detection of lung cancer increased significantly [2].

The possibility of wide use of early detection programs among the group at high risk of developing lung cancer may lead to detection of early stages of the disease and effective surgical treatment of lung cancer and, consequently, the possibility to restore the patient to a normal social life. When treatment begins at the early stage of the disease, it significantly reduces the cost of treatment. The Pomeranian Lung Cancer Screening Program was one of the first prophylactic programs based on LDCT to be implemented in Poland [17, 18].

While designing a preventive program, it is vital to know the target group and the main factors that induce people to participate in such projects. The PLCSP was available to all individuals from groups at high risk of developing lung cancer, who thus fulfilled the inclusion criteria for the program. It was observed that nearly half of the program participants were current tobacco smokers, whose family members also often smoked cigarettes, and who represented low or medium wealth status.

Contrary to other prophylactic programs conducted in Poland (such as cytology in cervical carcinoma [19], or mammography in breast cancer [20]), the popularity of the PLCSP has surprised everyone. The majority of people learned about the project from the media and from their family or friends. Surprisingly, not many participants learned about the program from the PLSCP website, although more than half of them declared that they had access to the Internet and that they were using it. Similarly, only a few participants heard about the program from healthcare employees. Therefore, the majority of the participants considered the information about the program to be insufficient, as in their opinion such information should come mainly from healthcare workers. Conversely, the participants judged positively the promotional campaign in the media; they considered it to be sufficient and essential for such programs. It is an important message for planning similar promotions in the future. However, it should be remembered that the participants of the PLCSP assessed the project in the presence of people who organised it free of charge. The respondents were grateful, so they might have attempted to present their final evaluation in a more positive way.

In such programs, knowledge of the main reasons that encourage high-risk individuals to participate in preventive programs is also very important. According to the participants of the PLCSP, the main factor that would induce them to participate in a prophylactic program would be the occurrence of worrying symptoms of the disease and neoplasm in a family member. However, only half of the respondents would make such an examination after recommendation by a doctor, although they declared earlier that the doctor is the person who should inform people about the possibility of participation in such a program.

Although there are numerous reasons for the need of conducting early lung cancer detecting programmes, currently we lack economic justification to realise them. The opponents of such programs argue that there is no social justification for financing such projects because, in their opinion, lung cancer patients are responsible themselves for the disease due to long-lasting tobacco smoking. Additionally, the costs of common use of LDCT in the group at high risk of lung cancer incidence would be too high for society due to the high number of target individuals. For instance, in the Pomeranian region, the high-risk group is estimated at 190,000 persons. The cost of a single LDCT examination is quite high (250-300 PLN), and it should be remembered that there is the necessity of follow-up examinations in the majority of participants, which additionally would raise the costs. Therefore, a significant issue in designing programs of early detection of lung cancer is to simulate the situation in which the examination will by partially paid by the participants. The conducted questionnaire concerning the readiness to co-finance the examination showed that the participants of the PLCSP were willing to take part in similar programs in the future, and to co-finance them. The respondents did not accept the idea of covering the total cost of the examination at the amount of 300 PLN, but most of them were willing to finance $1 / 3$ of the total cost of the examination by choosing the lowest from the proposed amounts, i.e. 100 PLN. However, it should be taken into account that it was a declared amount - participants often declare a higher amount than they would actually pay in reality. This result is also interesting as it allows a comparison between the amount of money the respondents spend on cigarettes with the sum they declared they would be prepared to spend on a prophylactic examination.

The majority of participants of the PLCSP declared that the distance of the facility at which the LDCT examination was made from their place of residence was of no importance 
to them; however, if such an examination was to be co-financed in the future, the respondents would be more willing to participate if the place of examination was close to their place of residence.

In an early detection program, it is also important to provide the participants with appropriate psychological support when they face the information about their disease. The clear majority of PLCSP participants responded to the information about the presence of changes in the lung parenchyma in a very emotional way, considering them to be neoplastic changes despite the fact that, in reality, most of them turned out to be false positive results. The disadvantage of the study is certainly a lack of further contact of persons conducting the questionnaire with the participants in whom radiological pathology was detected - it would be interesting to have information about the change in their emotional attitude towards the disease.

It should also be taken into account that such a prophylactic program should be accompanied by minimal anti-tobacco intervention (MIA), which includes medical advice to quit smoking. Nevertheless, currently the MIA is given without charge, and the costs of nicotine replacement therapy are covered by the patient; therefore, introduction of MIA in the screening program is feasible.

The knowledge obtained from the study is crucial for designing other prophylactic programs directed at early detection of lung cancer and financed with public resources. Such knowledge may help to reduce the social costs of similar programs. It seems that the optimal solution may be co-financing the program with its participants, which would possibly restrain its opponents from giving negative comments.

\section{Conclusions}

The Pomeranian Lung Cancer Screening Program directed at early detection of lung cancer turned out to be very popular among its participants.

The factors that motivated the participants to have the examinations were the following: the occurrence of neoplasm in the family, encouragement from the family or friends, and various promotional campaigns.

Most people from the group at high risk of lung cancer, who participated in the Pomeranian Lung Cancer Screening Program, were ready to co-finance the examination of low-dose computed tomography in the future.

\section{Conflict of interest}

The authors declare no conflict of interest.

\section{References:}

1. Henschke C.I., Yankelevitz D.F., Libby D.M., Pasmantier M.W., Smith J.P., Miettinen O.S. Survival of patients with stage I lung cancer detected on CT screening. N. Engl. J. Med. 2006; 355: 1763-1771.

2. Aberle D.R., Adams A.M., Berg C.D. i wsp. Reduced lung-cancer mortality with low-dose computed tomographic screening. N. Engl. J. Med. 2011; 365: 395-409.

3. SoneS., Nakayama T.,Honda T.i wsp.Long-term follow-up study of a population-based 1996-1998 mass screening programme for lung cancer using mobile low-dose spiral computed tomography. Lung Cancer 2007; 58: 329-341.

4. Gohagan J., Marcus P., Fagerstrom R. i wsp. Baseline findings of a randomized feasibility trial of lung cancer screening with spiral CT scan vs chest radiograph: the Lung Screening Study of the National Cancer Institute. Chest 2004; 126: 114-121.

5. Infante M., Lutman F.R., Cavuto S. i wsp. Lung cancer screening with spiral CT: baseline results of the randomized DANTE trial. Lung Cancer. 2008; 59: 355-363.

6. Blanchon T., Brechot J.M., Grenier P.A. i wsp. Baseline results of the Depiscan study: a French randomized pilot trial of lung cancer screening comparing low dose CT scan (LDCT) and chest X-ray (CXR). Lung Cancer. 2007; 58: 50-58.

7. Pedersen J.H., Ashraf H., Dirksen A. i wsp. The Danish randomized lung cancer CT screening trial-overall design and results of the prevalence round. J Thorac Oncol. 2009; 4: 608-614.

8. Menezes R.J., Roberts H.C., Paul N.S. i wsp. Lung cancer screening using low-dose computed tomography in at-risk individuals: the Toronto experience. Lung Cancer. 2010; 67: 177-183.

9. Swensen S.J., Jett J.R., Hartman T.E. i wsp. CT screening for lung cancer: five-year prospective experience. Radiology 2005; 235: 259-265.

10. Chong S., Lee K.S., Chung M.J. i wsp. Lung cancer screening with low-dose helical CT in Korea: experiences at the Samsung Medical Center. J Korean Med Sci. 2005; 20: 402-408.

11. Jemal A., Bray F., Center M.M., Ferlay J., Ward E., Forman D. Global cancer statistics. CA Cancer J Clin. 2011; 61: 69-90.

12. Krajowy Rejestr Nowotworów http://epid.coi.waw.pl/krn/

13. Molina J.R., Yang P., Cassivi S.D., Schild S.E., Adjei A.A. Nonsmall cell lung cancer: epidemiology, risk factors, treatment, and survivorship. Mayo Clin Proc. 2008; 83: 584-594.

14. Lilienfeld A.M., Kordan B. A Study of variability in the interpretation of chest X-rays in the detection of lung cancer. Cancer Res. 1966; 26: 2145-2147.

15. Henschke C.I., McCauley D.I., Yankelevitz D.F. i wsp. Early Lung Cancer Action Project: overall design and findings from baseline screening. Lancet 1999; 354: 99-105.

16. Laprus I., Adamek M., Kozielski J. Potrzeba badań przesiewowych w kierunku wczesnego wykrywania raka płuca - nowe dowody, nowe nadzieje. Pneumonol. Alergol. Pol. 2011; 79: 419-427.

17. Grodzki T., Walecka A., Fabian W. i wsp. Program wczesnego wykrywania nowotworów płuc za pomocą tomografii komputerowej - wstępne doświadczenia Szczecina. Pneumonol. Alergol. Pol. 2009; 77: 521-527.

18. Książek J., Dziedzic R., Jelitto-Górska M. i wsp. Pomorski Pilotażowy Program Badań Wczesnego Wykrywania Raka Płuca doniesienie wstępne. Ann. Acad. Med. Gedan. 2009; 39: 73-82.

19. Gottwald L., Giernat L., Lech W. Wyniki badania przesiewowego dla wczesnego wykrywania raka szyjki macicy u kobiet w regionie łódzkim. Ginekologia Polska 2002; 76: 934-938.

20. Kozimala M., Mrozowicz A., Ciechaniewicz W. Program badań profilaktycznych ukierunkowanych na zdrowie kobiety - ocena realizacji w powiecie lubaczowskim. Zdr. Publ. 2007; 117: $462-465$. 